\title{
Rapid isolation and characterization of polymorphic microsatellite loci in the mud crab, Scylla paramamosain (Portunidae)
}

\author{
H.F. Yao ${ }^{1}$, D.Q. Sun ${ }^{2}$, R.X. Wang ${ }^{2}$ and G. Shi ${ }^{2}$ \\ ${ }^{1}$ Fishery School, Zhejiang Ocean University, Zhoushan, P.R. China \\ ${ }^{2}$ Laboratory for Marine Living Resources and Molecular Engineering, \\ College of Marine Science, Zhejiang Ocean University, Zhoushan, P.R. China \\ Corresponding author: G. Shi \\ E-mail: sg2610105@126.com
}

Genet. Mol. Res. 11 (2): 1503-1506 (2012)

Received July 4, 2011

Accepted February 17, 2012

Published May 21, 2012

DOI http://dx.doi.org/10.4238/2012.May.21.7

\begin{abstract}
Scylla paramamosain is a widespread and commercially important species of coastal marine crab. We identified 13 polymorphic microsatellite loci from a genome library constructed with 5'-anchored PCR method. Thirty-two $S$. paramamosain from the East China Sea were used to analyze the characteristics of these loci. The number of alleles per locus ranged from 3 to 8 , with a mean of 5.923. Observed and expected heterozygosities ranged from 0.500 to 0.875 and from 0.500 to 0.859 , respectively. Eleven of the 13 loci were highly polymorphic (polymorphic information content $>0.5$ ). All of the 13 novel loci were in Hardy-Weinberg equilibrium after Bonferroni's correction ( $\mathrm{P}$ $<0.0038$ ). There was no null allele, stuttering errors or evidence of allelic dropout in any of the loci analyzed by MICRO-CHECKER. According to pairwise tests, no significant linkage disequilibrium was found among the 13 loci $(\mathrm{P}<0.0038$, adjusted value). These novel developed microsatellites will be useful for studies of genetic variation,
\end{abstract}


population structure, conservation genetics, and molecular-assisted selective breeding of S. paramamosain.

Key words: Scylla paramamosain; Microsatellite; 5'-anchored PCR

\section{INTRODUCTION}

The mud crabs of genus Scylla are distributed throughout the tropical and warm temperature zone in the west Pacific and Indian oceans, commonly inhabiting inlets or estuaries (Keenan, 1999). In China, Scylla paramamosain is one of the important commercial fishery resources, and aquaculture of $S$. paramamosain has had a long history (Cowan, 1985). To conserve and consistently exploit this fishery resource, population genetic research is necessary.

Microsatellite loci have been widely used as genetic markers for various population genetics studies because they are co-dominant, multi-allelic, easily scored, and highly polymorphic (Queller et al., 1993; Abreu et al., 2009; Babiker et al., 2011). Although some microsatellite markers have been developed in S. paramamosain (Takano et al., 2005; Xu et al., 2009; Ma et al., 2010; Cui et al., 2011), the molecular information in S. paramamosain is still limited in genetic mapping or molecular-assisted breeding of this species. Here, we report on 13 novel polymorphic microsatellite markers of S. paramamosain developed using 5'-anchored polymerase chain reaction (PCR).

\section{MATERIAL AND METHODS}

Genomic DNA was extracted from muscle tissue following the protocol of the traditional phenol-chloroform extraction with some modifications. A PCR-based library that was enriched for different microsatellite motifs was constructed by the 5'-anchored PCR technique (Fisher et al., 1996). Briefly, the sequences that contained microsatellite motifs were amplified by a single primer anchored at the 5'-end of microsatellite by seven degenerate bases (PCT6: 5'-KKVRVRV $(\mathrm{CT})_{6}, \mathrm{~K}=\mathrm{G} / \mathrm{T}, \mathrm{V}=\mathrm{G} / \mathrm{C} / \mathrm{A}, \mathrm{R}=\mathrm{G} / \mathrm{A}$ ). PCR amplification was carried out in a $25-\mu \mathrm{L}$ reaction mixture containing $1 \mathrm{X}$ PCR buffer (Tiangen, Beijing, China), $0.2 \mathrm{mM}$ dNTPs, $0.2 \mu \mathrm{M}$ of the degenerate primer, and $1 \mathrm{U} \mathrm{Taq}$ polymerase $(5 \mathrm{U} / \mu \mathrm{L}$; Tiangen). The amplification protocol was performed as follows: $95^{\circ} \mathrm{C}$ for $5 \mathrm{~min}, 7$ cycles of $95^{\circ} \mathrm{C}$ for $30 \mathrm{~s}, 60^{\circ} \mathrm{C}$ for $30 \mathrm{~s}$, and an extension for $1 \mathrm{~min}$ at $72^{\circ} \mathrm{C}$, then 35 cycles of $95^{\circ} \mathrm{C}$ for $30 \mathrm{~s}, 55^{\circ} \mathrm{C}$ for $30 \mathrm{~s}$, a 1 -min extension at $72^{\circ} \mathrm{C}$, and a final extension for $10 \mathrm{~min}$ at $72^{\circ} \mathrm{C}$. The PCR product showed consistent amplicons examined by electrophoresis on agarose gels. The amplicons between 300-1000 bp were purified and were then cloned to yield a genomic library of enriched microsatellites. Positive clones that appeared as single distinct bands on agarose gels were randomly selected for sequencing on an ABI 3730 automated sequencer. Specific primer pairs were designed flanking the microsatellite motifs using Primer Premier 5.0 and were synthesized by the company Genscript (Nanjing, China).

Characterization per locus was carried out based on genomic DNA of 32 individuals. PCR amplification was carried out in a $15-\mu \mathrm{L}$ reaction mixture containing $1 \mathrm{X}$ PCR buffer (Tiangen), $0.2 \mathrm{mM}$ dNTPs, $0.2 \mu \mathrm{M}$ of the specific primers, and $1 \mathrm{U}$ Taq polymerase (Tiangen, $5 \mathrm{U} / \mu \mathrm{L}$ ). The amplification protocol was performed as follows: $95^{\circ} \mathrm{C}$ for $5 \mathrm{~min}, 35$ cycles of $95^{\circ} \mathrm{C}$ for $30 \mathrm{~s}$, annealing temperature for $30 \mathrm{~s}$, and an extension at $72^{\circ} \mathrm{C}$ for $30 \mathrm{~s}$, and a final extension for $5 \mathrm{~min}$ at $72^{\circ} \mathrm{C}$. The specific annealing temperature per primer is listed in Table 1. PCR products were genotyped by denaturing $6 \%$ polyacrylamide gel electrophoresis 
(19:1, acrylamide:bis-acrylamide) using silver staining. Allele size was identified according to pBR322 DNA/MspI molecular weight marker (Tiangen).

The polymorphism data, number of alleles per locus $\left(N_{\mathrm{A}}\right)$, expected $\left(H_{\mathrm{E}}\right)$ and observed $\left(H_{\mathrm{O}}\right)$ heterozygosities, and Hardy-Weinberg equilibrium (HWE) were determined by the program Popgene 32 (Yeh et al., 2000). Polymorphism information content (PIC) was calculated by the formula: PIC $=1-\sum_{i=1}^{n} p_{i}^{2}-2 \sum_{i=1}^{n} \sum_{k=1}^{n} p_{i}^{2} p_{j}^{2}$, where $P_{i}$ and $P_{j}$ are frequencies of the $i$ and $j$ allele, respectively (Boestein et al., 1980). The ARLEQUIN 3.11 software was used to calculate genotypic linkage disequilibrium between these loci (Excoffier et al., 2006). All results for multiple tests were corrected using Bonferroni's correction (Rice, 1989).

\section{RESULTS AND DISCUSSION}

Of the 80 sequenced clones, 29 primer pairs flanking the microsatellite motifs were synthesized. Among the 29 loci, 13 loci were successfully amplified and shown to be polymorphic. The 13 single loci were distributed in 10 sequences, which have been submitted to GenBank (JN117280-JN117289). Characteristics of the newly developed microsatellite loci and variability validated by 32 individuals of $S$. paramamosain were summarized in Table 1. $N_{\mathrm{A}}$ for each locus ranged from 3 to 8 , with an average of 5.923. $H_{\mathrm{O}}$ and $H_{\mathrm{E}}$ ranged from 0.500 to 0.875 and from 0.500 to 0.859 , respectively. The usual PIC values of microsatellites ranged from 0.427 to 0.981 , where 11 loci were highly polymorphic (PIC $>0.5$ ). All of the 13 novel

\begin{tabular}{|c|c|c|c|c|c|c|c|c|c|c|}
\hline Locus & $\begin{array}{l}\text { GenBank } \\
\text { accession No. }\end{array}$ & Primer sequence $\left(5^{\prime}-3^{\prime}\right)$ & $\begin{array}{l}\mathrm{Tm} \\
\left({ }^{\circ} \mathrm{C}\right)\end{array}$ & $\begin{array}{l}\text { Repeat } \\
\text { motif }\end{array}$ & $\begin{array}{l}\text { Size range } \\
\quad(\mathrm{bp})\end{array}$ & $N_{\mathrm{A}}$ & PIC & $\begin{array}{c}\mathrm{HWE} \\
(\mathrm{P})\end{array}$ & $H_{\mathrm{O}}$ & $H_{\mathrm{E}}$ \\
\hline Scse15-1 & JN117280 & $\begin{array}{l}\text { TCTCCCTTCCTGACTACT } \\
\text { AAACTTTGTCCTGCCATC }\end{array}$ & 48 & $(\mathrm{CCT})_{7}$ & $265-280$ & 4 & 0.703 & 0.416 & 0.625 & 0.750 \\
\hline Scse43-1 & JN117281 & $\begin{array}{l}\text { GAAATCTGAGCTGCCAATC } \\
\text { CACCCATCCAAGTACCAA }\end{array}$ & 48 & $(\mathrm{TG})_{15}$ & $216-238$ & 8 & 0.899 & 0.149 & 0.750 & 0.844 \\
\hline Scse43-3 & JN117281 & $\begin{array}{l}\text { ATTTCATTAGTTAGCCAC } \\
\text { ACCCATAGTCGTAGTTGT }\end{array}$ & 58 & $(\mathrm{ACT})_{7}$ & $139-157$ & 8 & 0.746 & 0.733 & 0.875 & 0.750 \\
\hline Scse 53-1 & JN117282 & $\begin{array}{l}\text { CCGTCACTTCACAGTATA } \\
\text { GTTTTCATTTGAGTTTCC }\end{array}$ & 48 & $(\mathrm{CA})_{32}$ & $266-300$ & 7 & 0.770 & 0.474 & 0.750 & 0.797 \\
\hline Scse 72-2 & JN117283 & $\begin{array}{l}\text { GGTCCAAATCGAATGTCC } \\
\text { ATAAGCCAAGGTTCTACTC }\end{array}$ & 50 & $(\mathrm{TG})_{9}$ & $196-252$ & 8 & 0.843 & 0.655 & 0.875 & 0.859 \\
\hline Scse $85-1$ & JN117290 & $\begin{array}{l}\text { AAACAGATTGGCGTCCTC } \\
\text { CCACGATTTACCGAGAAG }\end{array}$ & 45 & $(\mathrm{AGG})_{5}$ & $303-315$ & 6 & 0.981 & 0.999 & 0.625 & 0.508 \\
\hline Scse96-1 & JN117284 & $\begin{array}{l}\text { CTTCCTCACCGTCCCTAT } \\
\text { CTCTGTTGCCTAATTCCTC }\end{array}$ & 47 & $(\mathrm{GAAGG})_{10}$ & $262-307$ & 8 & 0.809 & 0.227 & 0.750 & 0.828 \\
\hline Scse97-1 & JN117285 & $\begin{array}{l}\text { AAAAGCAGTTCGTTGTTA } \\
\text { TAGACTGGTGGAAGGATG }\end{array}$ & 47 & $(\mathrm{CAA})_{8}$ & $238-259$ & 6 & 0.720 & 0.920 & 0.875 & 0.758 \\
\hline Scse99-1 & JN117286 & $\begin{array}{l}\text { ATTCAGCGGGAATGGGATG } \\
\text { ACGAGCCACAGCAAGAGCC }\end{array}$ & 54 & $\begin{array}{l}(\mathrm{GGAG})_{3} \cdots \\
(\mathrm{GGAG})_{2}\end{array}$ & $148-152$ & 5 & 0.670 & 0.047 & 0.750 & 0.719 \\
\hline Scse99-2 & JN117286 & $\begin{array}{l}\text { CTTGCTGTGGCTCGTTTG } \\
\text { CTCGGTGCGAATATCAGT }\end{array}$ & 50 & $(\mathrm{TCC})_{6}$ & $288-300$ & 3 & 0.468 & 0.096 & 0.500 & 0.531 \\
\hline Scse101-1 & JN117287 & $\begin{array}{l}\text { GTATTTTGCCTGTCTGCC } \\
\text { ACCGCTATTATCCTCCAC }\end{array}$ & 56 & $(\mathrm{GT})_{13}$ & $131-147$ & 6 & 0.748 & 0.416 & 0.875 & 0.781 \\
\hline Scse109-1 & JN117288 & $\begin{array}{l}\text { AATAGCCATACTGGAAGC } \\
\text { AATCAGACCAAGGAGGTT }\end{array}$ & 48 & $(\mathrm{TGC})_{12}$ & $226-268$ & 5 & 0.679 & 0.805 & 0.875 & 0.727 \\
\hline Scse118-1 & JN117289 & $\begin{array}{l}\text { CCTAATCCAATCCAACCT } \\
\text { TCTCCCCACATTCTCATA }\end{array}$ & 47 & $(\mathrm{GA})_{6}$ & $254-258$ & 3 & 0.427 & 0.644 & 0.714 & 0.500 \\
\hline Average & & & & & & 5.923 & 0.728 & & 0.757 & 0.721 \\
\hline
\end{tabular}


loci obeyed HWE in the sampled population, after Bonferroni's correction $(\mathrm{P}<0.0038$, adjusted value). There was no null allele, stuttering errors or evidence of allelic dropout in any of the loci analyzed by MICRO-CHECKER (Van Oosterhout et al., 2004; Bonferroni's correction). No significant linkage disequilibrium was found between all pairs of these 19 loci after Bonferroni's correction $(\mathrm{P}<0.0038$, adjusted value). None of these 13 loci was similar to any of the sequences in GenBank by a homology search using the BLAST program.

Overall, the 13 novel microsatellite loci developed in S. paramamosain were highly polymorphic. They will be helpful in studies of genetic variation, population structure, conservation genetics, and molecular-assisted breeding of this species in the future.

\section{ACKNOWLEDGMENTS}

Research supported by Important Science and Technology Specific Projects of Zhejiang Province (\#2009C12080, \#2011C12011).

\section{REFERENCES}

Abreu MM, Pereira LHG, Vila VB, Foresti F, et al. (2009). Genetic variability of two populations of Pseudoplatystoma reticulatum from the Upper Paraguay River Basin. Genet. Mol. Biol. 32: 868-873.

Babiker HM, Schlebusch CM, Hassan HY and Jakobsson M (2011). Genetic variation and population structure of Sudanese populations as indicated by 15 Identifiler sequence-tagged repeat (STR) loci. Investig. Genet. 2: 12.

Botstein D, White RL, Skolnick M and Davis RW (1980). Construction of a genetic linkage map in man using restriction fragment length polymorphisms. Am. J. Hum. Genet. 32: 314-331.

Cowan L (1985). Crab Farming in Japan, Taiwan and the Philippines. Queensland Department of Primary Industries, Queensland.

Cui H, Ma H, Ma L, Ma C, et al. (2011). Development of eighteen polymorphic microsatellite markers in Scylla paramamosain by 5'anchored PCR technique. Mol. Biol. Rep. 38: 4999-5002.

Excoffier L, Laval G and Schneider S (2006). ARLEQUIN Ver 3.1: An Integrated Software Package for Population Genetics Date Analysis. Genetics and Molecular Genetics Population Lab, Institute of Zoology. University of Geneva, Switzerland.

Fisher PJ, Gardner RC and Richardson TE (1996). Single locus microsatellites isolated using 5' anchored PCR. Nucleic Acids Res. 24: 4369-4371.

Keenan CP (1999). Aquaculture of the Mud Crab, Genus Scylla Past, Present and Future. In: Mud Crab Aquaculture and Biology (Keenan CP and Blackshaw A, eds.). Proceeding of an International Scientific Forum Held, Darwin, 9-13.

Ma HY, Ma CY, Ma LB and Cui HY (2010). Novel polymorphic microsatellite markers in Scylla paramamosain and cross-species amplification in related crab species. J. Crust. Biol. 30: 441-444.

Queller DC, Strassmann JE and Hughes CR (1993). Microsatellites and kinship. Trends Ecol. Evol. 8: 285-288.

Rice WE (1989). Analyzing tables of statistical tests. Evolution 43: 223-225.

Takano M, Barinova A, Sugaya T, Obata Y, et al. (2005). Isolation and characterization of microsatellite DNA markers from mangrove crab, Scylla paramamosain. Mol. Ecol. Notes 5: 794-795.

Van Oosterhout C, Hutchinson WF, Wills DPM and Shipley P (2004). MICRO-CHECKER: software for identifying and correcting genotyping errors in microsatellite data. Mol. Ecol. Notes 4: 535-538.

$\mathrm{Xu}$ XJ, Wang GZ, Wang KJ and Li SJ (2009). Isolation and characterization of ten new polymorphic microsatellite loci in the mud crab, Scylla paramamosain. Conserv. Genet. 10: 1877-1878.

Yeh FC, Yang R, Boyle TJ, Ye Z, et al. (2000). PopGene32, Microsoft Windows-Based Freeware for Population Genetic Analysis, Version 1.32. Molecular Biology and Biotechnology Centre, University of Alberta, Edmonton. 